\title{
Anthrovision
}

Vaneasa Online Journal

\section{Screening Transnational Spaces}

Anthropology's spatial paradigms and the construction of cinematic space in ethnographic film

\section{Steffen Köhn}

\section{(2) OpenEdition}

\section{Journals}

Electronic version

URL: http://journals.openedition.org/anthrovision/1449

DOI: 10.4000/anthrovision. 1449

ISSN: 2198-6754

\section{Publisher}

VANEASA - Visual Anthropology Network of European Association of Social Anthropologists

\section{Electronic reference}

Steffen Köhn, « Screening Transnational Spaces », Anthrovision [Online], 2.2 | 2014, Online since 09 January 2015, connection on 01 May 2019. URL : http://journals.openedition.org/anthrovision/1449 DOI : 10.4000/anthrovision. 1449

This text was automatically generated on 1 May 2019.

(C) Anthrovision 


\section{Screening Transnational Spaces}

Anthropology's spatial paradigms and the construction of cinematic space in ethnographic film

\section{Steffen Köhn}

\section{Introduction}

1 In this article, I want to unravel the relationship between the conception of space in anthropological thinking and the construction of cinematic space in ethnographic film. First, I will show how anthropology's basic theoretical assumptions on space are not only reflected, but literally inscribed in the works of ethnographic filmmakers. This analysis will then form the background for an exploration of how innovative cinematic practices may in turn profoundly influence the spatial perspectives of contemporary theorizing and thus lead to methodological innovation. As George Marcus (1994) has famously shown two decades ago, cinematic techniques like montage may provide powerful metaphors for anthropological debates on representation as they give conceptual form to some of the discipline's urgent concerns, namely how to employ multiperspectivity and multivocality to approach the increasing complexity of our globalized present. Marcus' notion of montage as a methodological tool has since proven to be extremely influential for anthropological thinking (Suhr \& Willerslev 2012, 2013; Kiener 2008; Taussig 1987, 2004; Willerslev \&Ulturgashewa 2007). Yet whereas Marcus evokes film only to make an argument about anthropological writing, I will instead introduce films by Wilma Kiener, Aryo Danusiri and myself as points of departure for a rethinking of recent anthropological concepts of space and place. Hence, I argue that innovative cinematic practices derived from experimental film and video art do not only expand the language of ethnographic film but may also alter our theoretical understanding of space and place in a globalized world. 


\section{The conception of space in realist modes of representation}

2 In much classical anthropological research and writing, space and place have been taken for granted. In traditional notions of fieldwork and 'realist' modes of representation it is assumed that anthropology's 'objects of study' exist in non-Western, non-industrialized locales and, thus, in intact and coherent spatial and temporal relations. In this view, space and place are simply locations, unproblematic frames for the things people do. In the wake of the postmodern critiques of the 1980s and 90s, Arjun Appadurai (1988) has noted that anthropologists have often used specific places to locate particular groups of people and exemplify anthropological concepts with them. India, for example, has been made as to stand in for hierarchy and the caste system. Liisa Malkki (1992) has raised a similar critique against such an abstract conception of space as mere setting for culture. She challenges equations of identity with territory, culture with place. For her, the territorialization of cultures is tantamount to their spatial incarceration. 'Terms like 'native', 'indigenous', and 'autochthonous' have all served to root cultures in soils' (1992: 29) and, thereby, made them appear as cut off from all global influences and connections. The 'field' in which anthropological practice takes place thus often is imagined as a remote, confined, and consistent place, which the ethnographer enters in a form of 'intensive dwelling' (Clifford 1997: 58) and leaves after a time of deep, extended research. As Clifford notes, this conception of the field was modeled after the natural sciences and played an important part in the discipline's self-definition and its delineation from other sciences and cross-cultural practices. Effectively, it stipulated the segregation of the anthropologist's world from the static, fixed and timeless cultural world s/he describes.

Ethnographic filmmakers equally have taken part in such a 'sedentarist metaphysics' (Malkki 1992: 31). The films of the observational cinema tradition construct ethnographic locales in a fixed spatial-temporal unity. The observational method, as for example Paul Henley promotes it, seeks to 'capture the rhythms and spatial configurations of the social world represented' (2004: 115). To achieve this, Henley favors long sequence shots that reproduce a quasi-natural relation of space and time over marked interventions into the filmic material. The characteristic mode of representation in observational cinema is therefore based on an insistence on the integrity of the pro-filmic world. As Anna Grimshaw notes (2001: 131), the truth of such a representation has to be embodied by the observational filmmaker. $\mathrm{S} /$ he is the witness, the one who has genuinely 'been there'. The effect that observational filmmaking shall produce in the audience thus corresponds closely with this paradigm of realist ethnographic representation: 'you are there, because I was there'. ${ }^{1}$ We, the spectators, are made to share the observational standpoint of the anthropologist and her/his camera. Hence, cinematic space in conventional ethnographic film is constructed around the illusion of being present in the field site. In To Live with Herds (MacDougall 1972), for example, David MacDougall wanted to give his audience the feeling of actually being situated among the people and cattle within a Jie compound in northeastern Uganda (MacDougall 1998: 200). This impression is achieved through an unobtrusive, conjunctive style of editing and a 'humanized, situated camera with its flawed, partial view' (Grimshaw and Ravetz 2009: 83). It allows for a continuity of perception from the perspective of an individual observer that is tied 'to the specific historical act of filming' (MacDougall 1998: 205). A particular example for this is a long 
uninterrupted shot in which MacDougall's camera slowly moves around his protagonist Logoth as he maps the topography of the Jie territory. Logoth points to the different cardinal directions and explains the surrounding landscape, describes the neighbors of the Jie and locates the feeding grounds of the cattle. Logoth, and with him the camera in this shot are the still point from where the territory is observed. For the audience, orientation within the diegetic space of the film is thus achieved through the eyes of the human observer whose perspective the camera takes on. Jie lifeworld in To Live with Herds is thus explored through Logoth's firm emplacement in it.

4 In an age of transnational movement however, such representations of rooted, immobile, coherent, and unaffected cultural worlds have become questioned, and the same goes for the stable standpoint from which they could be observed. For anthropology, the increasing global mobility and interconnectedness of people, places, things, stories, or conflicts thus poses new epistemological problems. It demands new methods of research and representation that also go beyond the rather constricted subject matters encountered in most observational films. In a globalized world, as Smith notes, the 'challenge is to develop an optic and a language capable of representing the complexity of transnational connections, the dynamics of cross-border networks, and the shifting spatial scales at which agency takes place' (2001: 174).

\section{Representing Transnationalism}

5 In two highly influential articles, George Marcus $(1994,1995)$ has argued that in order to come to terms with the increased dissemination of actors, goods, knowledge, ideas, and economic entities on a global scale, anthropologists would have to leave the 'misé en scene' of their traditional field sites and take on a systemic perspective. For Marcus, anthropology's focus on single-site investigations and bounded concepts severely limits perception and analysis. Therefore, he calls for a mobile ethnography based on multisited fieldwork in which the anthropologist follows the 'circulation of cultural meanings, objects and identities in diffuse time-space' (1995: 96). This methodological revolution, however, must go hand in hand with new modes of representation, as problems of representation have to be understood as anthropology's 'distinctive medium of theoretical and methodological discourse' (1994: 51). For Marcus, traditional realist forms of representation cannot account for the complexity of a globalized present. He therefore proposes that anthropologists should embrace the artistic principle of montage as an excellent inspiration for contemporary ethnography. Montage for Marcus is a means for transcending the limitations of the micro perspective of a situated observer and her/his subject-centered vision. Rather, it can enable an enhanced perception of connections and causalities on the macro level of global structures as it allows the comparison and juxtaposition of different locales. What is striking, however, is that Marcus evokes the 'cinematic metaphor of montage' only for innovation in ethnographic text-production. His ideas have not yet had a broad impact on ethnographic filmmakers, who still show a great deal of suspiciousness towards more expressive forms of montage and rather constrict themselves to single-site, single-observer concepts.

6 Wilma Kiener has thus, in a much read article, proposed an 'ethnographic cinema of montage' as an alternative cinematic poetics that is 'capable of understanding and conveying the experience of living in worlds of (dis)location and of (a)synchronism' (2008: 393). She argues that transnational subjects (migrants, refugees, travelers) 
experience global processes foremost in the form of absences: the homeland, the family and friends that are left behind, the political protest that is only possible in a foreign state. She explores how montage can address these absences by adding another, additional reality to the actual observational scene, thereby expanding and enhancing it (2008: 395). What is absent can thus be expressed as a necessary part of the whole. Kiener's film Ixok-Woman (Kiener 1990) portrays the Guatemalan actress and dancer Carmen Samayoa in her European exile. As critical intellectuals, Carmen and her partner Edgar Flores were threatened by a paramilitary organization during the Guatemalan Civil War and had to leave their country. The film follows them touring Germany and Austria with a performance in which Carmen takes on the stage persona of a Guatemalan peasant woman who becomes a victim of the violence inflicted on the indigenous population by the military regime. Whilst filming, Kiener was confronted with the challenge to deal with the multiple absences in Carmen's life. Accompanying her in Europe, she found it difficult to find scenes that conveyed Carmen's experience of exile, as her personal background and the political context that made her flee lay elsewhere. Furthermore, Carmen's pantomime performance also played with absences, evoking a multiplicity of people and situations onstage with almost no props and stage design. To fill these voids, Kiener decided that she had to film in Guatemala. As it was too dangerous for Carmen to return, Kiener sought to document scenes that expressed the situation there and that would tie into the film's overarching narrative. She then connected both realities in a style of editing that Gilles Deleuze (1986: 28) describes as 'false continuity'. For Deleuze, classical (traditional, or mainstream) cinema is determined by the continuity of movement. In what he calls 'movement image cinema', editing serves to establish an uninterrupted progression of actions and reactions in a coherent cinematic space. In IxokWoman, however, Kiener frequently joints two different geographical spaces, thereby visually creating an abstract transnational space.

In one scene, for example, we see Carmen on the passenger seat of the ramshackle bus in which she and Edgar tour Germany. She is looking out of the window onto the rainsoaked highway. With the next shot, however, we are suddenly transported to a Guatemalan country lane where a blue truck passes from the right. The following shot then, in a similar graphic composition, brings us back to the rainy German expressway. This works seamlessly, as these shots are sutured according to the editing convention of the so-called eyeline match. As we have seen Carmen look out of the window, we accept the following shot as her point of view. ${ }^{2}$ False continuity editing is used here to hint at the important presence of another reality, in this case the homeland longingly remembered by a person in exile. Thus, Kiener is able to include what Deleuze calls the 'virtual' aspects of a given reality: The memories and imaginations of her protagonist, as well as her feeling of deterritorialization. This style of editing culminates in a harrowing montage sequence that expresses the political reality of Guatemala's Civil War, a situation that produced a multitude of exiles and absentees (all those who have been kidnapped, killed or disappeared). It unfolds by interweaving Carmen's stage performance with authentic documentary material. Alone on an empty stage dimly lit in red, Carmen performs how a village raid by the military forces turns into a massacre. This is intercut with footage that Kiener filmed in a training camp of the Guatemalan army. Thus, following Carmen's fearful gaze towards the approaching soldiers on stage, we actually see them leaving their ambush and storming into a clearing. With the next shot, we are back on Carmen as she performs the rape of the village women by the soldiers. Then, in a fast-cut alternation of 
images, we see the Guatemalan troops practicing shooting and a disquieting dance by Carmen, in which her body trembles as if shattered by the impact of their bullets.

This cinematic representation of action and reaction, cause and effect is entirely constructed. Yet it works, as in both actions the counterpart is absent: the enemies in the soldiers' training operation are only imagined, as is the military presence in Carmen's performance. It is the combination of these images that creates the truth of the sequence, a veracity of a higher order, irrespective of exact time and historical place (Kiener 2008: 407). It strongly evokes the context of political violence that forced Carmen into exile without recourse to conventional realist means of representation like interviews or eyewitness accounts. Kiener's creative use of montage thus provides a powerful means to convey the spatial and temporal disruptions, the gaps that are so constitutive of the experience of exile.

Excerpt from Ixok- Woman. The actual montage sequence starts at 2:15.

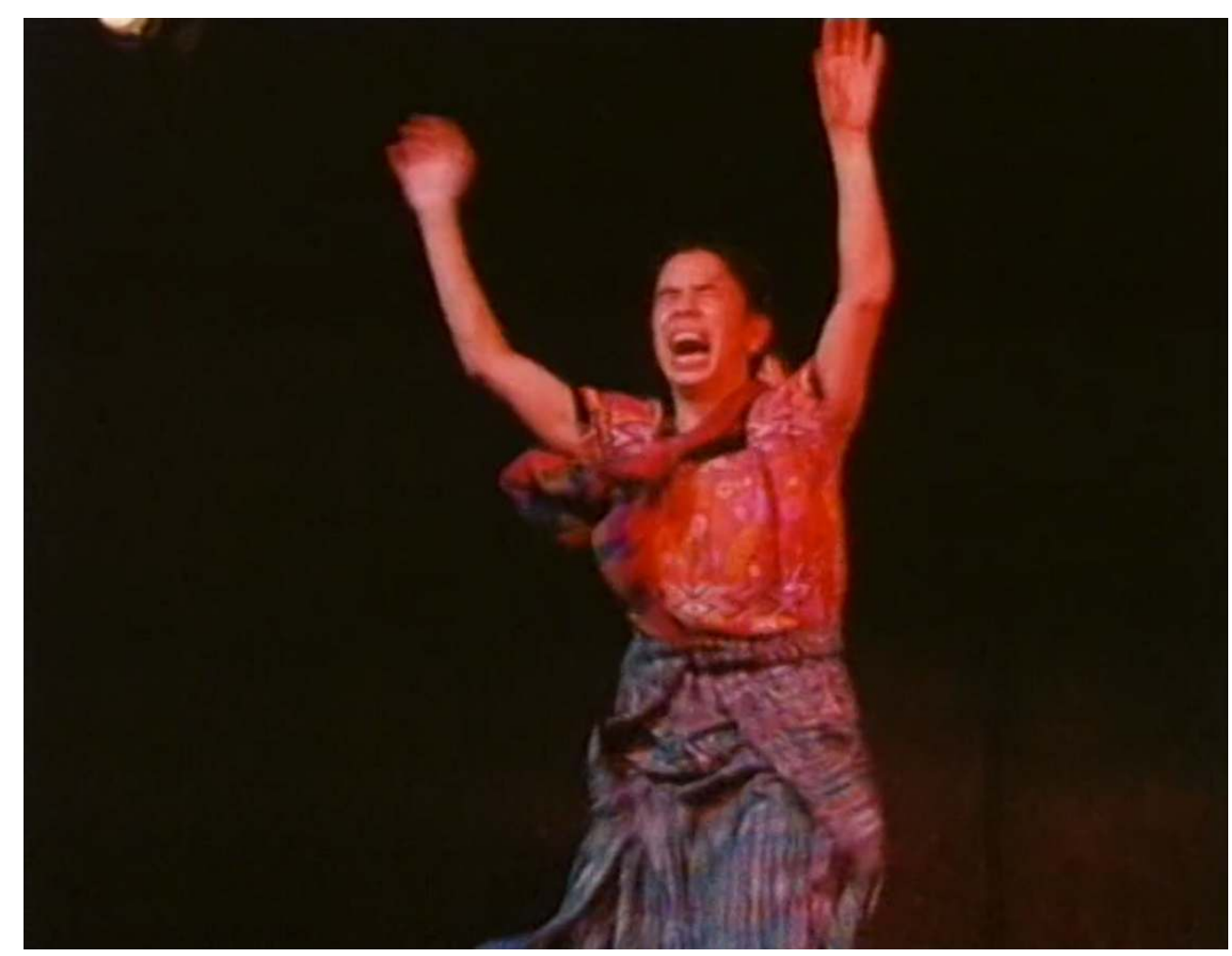

Click here to watch video: http://www.youtube.com/watch?v=d5EiF712010

Wilma Kiener

9 Kiener's ethnographic cinema of montage thus gives cinematic form to anthropological research designs that are concerned with 'chains, paths, threads, conjunctions, or juxtapositions of locations' (Marcus 1995: 105). It can thus be seen as an aesthetic translation of the notions of 'flow', 'scape', and 'network' that shape contemporary cultural theory (e.g., see Hannerz 1996; Appadurai 1996; Castells 2000a, 2000b, 2004; Urry 2003; Clifford 1997). Within this 'new mobilities paradigm' (Sheller and Urry 2006), culture is rethought through the prism of movements and interconnections. This current orientation towards mobility and transnational processes has effectively overturned some all-too static conceptions of cultures as coherent 'wholes' within anthropology as well as a widespread 'methodological nationalism' within the social sciences (Amelina et. 
al. 2012). Yet the 'nomadic metaphysics' of contemporary theorizing (Cresswell 2002) that values the routes of the migrant or traveller over the roots of located identities, also has its analytical shortcomings. The emphatic focus on movements, paths, nodes, and networks and the obsession with relationality and connectivity only allows for a cursory understanding of space and, moreover, underestimates the significance of place. If places are only examined for their interconnectedness, this profoundly marginalizes the theorization of their particularity, depth and history as lifeworld and, thereby, the actual strength and primary context of committed anthropological research. Therefore, anthropology has to develop a timely understanding of space and place, one that goes beyond both the sedentarist concept of place as a mere 'container for culture' and an exclusive focus on flows and networks that brings solely the global dimension into view. The abstraction of such a systemic perspective neglects individual actors and their practices and is thus unable to describe how global mobility is emplaced, how it thoroughly affects concrete places. Thus, as Jackson et al. (2004) argue, space and place have to be seen as constitutive of transnationality. Understanding transnational mobility through an emphasis on place is therefore not as oxymoronic as it may at first seem. As Aydemir and Rotas note, '(m)igration not only takes place between places, but also has its effects on place, in place' (2008: 7). Migration 'installs movement within place', making place the 'setting of the variegated memories, imaginations, dreams, fantasies, nightmares, anticipations, and idealizations that experiences of migration, of both migrants and native inhabitants, bring into contact with each other' (ibid., emphasis in original).

\section{Places in transition}

10 Places are, as Cresswell points out, 'never complete, finished or bounded but are always becoming - in process' (2002: 20). This dynamics, however, is difficult to explore with the methodological toolkit of multi-sited ethnography. Marcus' imperative of 'tracking' a particular object of study (be it an actor, a symbol, or an idea) will certainly reveal its dynamism, yet it produces only static snapshots of the multiple sites that are involved. What changes occur in the migrant's home village after s/he has left? How does her/his emigration affect those who are left behind? And don't we have to understand these changes as an important part of the phenomenon 'migration' even though no further movement is involved? To arrive at a theoretical perspective that is attentive to the transformative qualities of places, it is useful to take a look at the recent rethinking of place in contemporary geography. In what has inaugurated a 'spatial turn' in the wider fields of social science, cultural geographer Edward Soja (1996) has applied theories of social practice to describe space and place as lived and inhabited. For Soja, space has no meaning by itself and therefore cannot be understood as distinct from the social sphere. Drawing upon the work of Henri Lefebvre (1991) who analyzed space as a product of complex social construction, he seeks to overcome the binary opposition between objective (measurable, or cartographic) and subjective (perceived, or imagined) space. Rather, his notion of 'third space' understands space as practiced and performed. Hence, Soja's work provides the theoretical groundwork for a much-needed exploration of the politics of space and place, for as Rodman notes, we cannot understand place without emphasizing 'the agency of individuals and of forces beyond individual control' (2003: 205). 
11 In this vein, Doreen Massey (2005) has offered a groundbreaking work that is essential for an understanding of the spatial in political terms. Like Soja and Lefebvre, she seeks to overcome the 'taming' conceptualizations of space as static, permanent, and closed. Instead, her work is based on three intertwined premises: Space is always the product of interrelations and interactions. Space provides a sphere of possible multiplicity and of coexisting heterogeneity. Space is always under construction, always in the process of being (re-) made (2005: 9). Massey then understands places as 'integrations of space and time, as spatio-temporal events' (2005: 130, emphasis in the original). They are constituted by both what happens inside of them and by their relations to the outside, to other locations, actors, or things. Hers is a progressive, a radically open sense of place, one that challenges not only essentialist concepts of place as circumscribed and settled, but equally those all-too abstract notions of global flows and movements that are devoid of social content and thus make place all but disappear. She sees places as constellations of trajectories, as intersections in the meshwork of global relations, as 'articulations of the wider power-geometries of space' (2005: 130). Therefore, their 'throwntogetherness', their multiplicity and changing nature demand negotiation. As we cannot assume any pre-given coherence, community or collective identity that can be ascribed to them, they pose a political challenge (2005: 141$)$. A politics of place thus has to consider internal and external relations, processes of inclusion and exclusion, the local context and the global dimension. Hence, space and place constitute the very ground of the political because it is in place where we engage with the question of coexistence.

\section{The materiality of place}

12 How can such a rethinking of place be reflected in ethnographic filmmaking? As we have seen in the discussion of To Live with Herds, the film medium undoubtedly has a unique capacity to convey the concrete materiality of place. A situated and insisting style of filmmaking that is attentive to the slow unfolding of events in front of the camera might thus offer the spectator a phenomenological engagement with the particularities of a given lifeworld. Therefore, we should not all too readily discard the cinematic techniques that invite for this kind of viewing experience. Such a sense of the lived experience of place is, for example, not provided by Kiener's disruptive montage spaces that demand a reflexive mode of spectatorship and are not 'inhabitable' in a phenomenological sense. Kiener herself states that her constructivist mode of montage aims at a veracity of a higher order in which the concrete situation of time and place become unimportant (2008: 407). Her dismissal of the techniques of observational filmmaking like long takes and extended sequences, therefore, might deprive us of a cinematic methodology that is suitable for the investigation of the (often subtle) transformations that occur in place.

13 An exemplary work that explores such a complex metamorphosis of space, materiality and identities by transforming the language of observational cinema into something new is Aryo Danusiri's experimental video The Fold (2011). It proves that a long-take aesthetic not necessarily produces the impression of coherence and stasis, as Kiener's critique implies. Filmed in the Masjid Manhattan, a basement mosque in downtown New York that is frequented by migrants from Asia, Africa, and the Middle East, The Fold observes the fluid transitions between sacred and secular space. Consisting only of one uninterrupted long shot, the video begins with showing a religious service. Throughout the whole event, the camera remains in a fixed position at a high angle covering almost everything of the 
room. After the prayer, however, we witness how the space slowly begins to transform. The blue mats that meticulously covered the floor on which the men were praying (and which they only dared to enter with their bare feet) are one after the other folded together and stored away. At the end of the 12-minute long sequence shot then, a pingpong table is set up on the red vinyl flooring of the basement and the mosque has changed back into a community center. Danusiri thus shows how space is a product of performance. There is nothing intrinsically sacred or profane about this place. Such qualities are only constituted by collective acts of worship or leisure.

The smooth transition from sacred to secular space in Aryo Danusiri's The Fold.

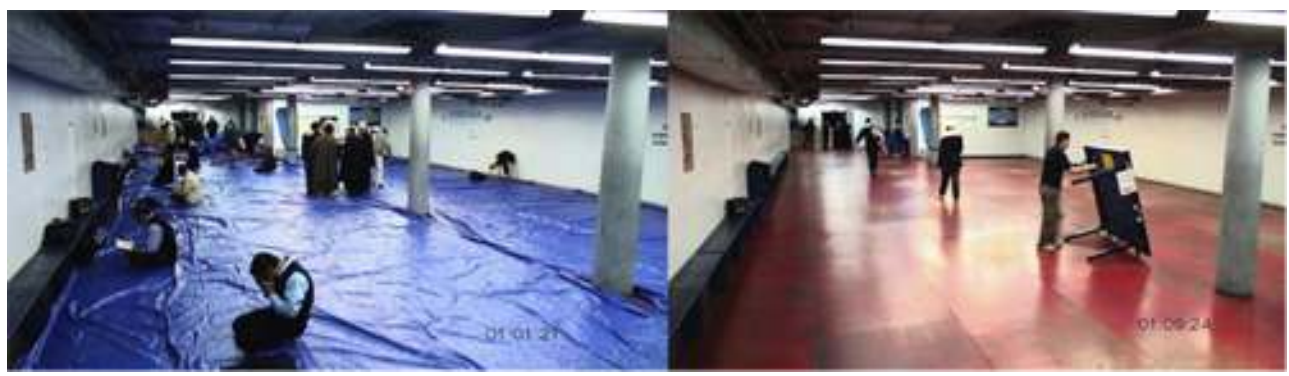

Aryo Danusiri

For the members of the Masjid Manhattan, however, the mobility of their mosque is an unwelcome necessity. When the lease contract for their original space was terminated (after almost four decades) by the new owner of the building, it proved to be almost impossible to find a new location. In the aftermath of the 9/11 attacks, the mosque's committee was everywhere confronted with doubt and suspicion. Eventually, the community even was drawn into the heated discussions around the 'Ground Zero Mosque' in which the appropriateness of building an Islamic center near the World Trade Center site was publicly disputed. Since then, the mosque is located in the multi-functional basement owned by the Asian-American Cultural Center of Tribeca that rents out the space in time units of two-hours. Thus, the spatial transformation that Danusiri's video investigates points to wider political processes such as the exclusion of minority groups and the negotiation of coexistence in a multicultural and multireligious city.

\section{Shifting between perspectives: the video installation $A$ Tale of Two Islands}

15 At this point, I want to discuss how the theoretical and methodological considerations I have presented so far have informed my own filmmaking practice. Therefore, I want to introduce my two-screen video installation A Tale of Two Islands (Köhn 2012) as an attempt to productively combine the long-take aesthetics of observational film with the reflexive techniques of constructive montage. This work is inspired by the spatial practices of contemporary installation art, which, as I have argued elsewhere (Köhn 2013), offer an interesting potential for the organisation and dissemination of ethnographic material in terms of multivocality and multiperspectivity. A Tale of Two Islands is based on multi-sited fieldwork that I have conducted on the French island Mayotte and its neighbour-island Anjouan, which politically belongs to the Union of the Comoros. Geographically, both islands are part of the Comoros archipelago in the Indian Ocean. Politically, Mayotte and 
Anjouan both belonged to the French colonial empire until 1974. In this year, referendums were organized on both islands in which the inhabitants could vote for independence. Whereas a great majority on Anjouan (as on the other two Comoros islands Mohéli and Grande Comore) chose to depart from France, the Mahorans wanted to remain under the protective and wealthy French administration.

This decision can only be understood in light of the fact that Mayotte, as the first of the islands that was colonized, had always profited most from the presence of the French colonial administration that put many islanders into work and stimulated economic activity (Boisadam 2009: 45). While Mayotte has since been integrated into the French state (finally becoming its 101 Department in 2011) and is, since January 2014, also part of the European Union as one of its 'Outermost Regions', the Union of the Comoros is politically unstable and ranks 169th out of 187 countries in the 2012 Human Development Index. This political separation has thus resulted in a complex postcolonial situation. While both islands for centuries formed a cultural unity and inter-insular trade, migration, and family relationships were the norm, the new maritime border now is firmly controlled by the French Police aux Frontières and the citizens of the Union of the Comoros require a visa to enter Mayotte. Due to the severe economic imbalances between Mayotte - an artificial enclave that offers social security, wages, and education on European standards - and the other Comoros islands which form one of the poorest nations in Africa, many Anjouans try to migrate to Mayotte in search of a job and a better future. Because of the tight border controls, their only way to reach the neighbor-island, however, is the night-time crossing with a small motorboat, a so called Kwassa Kwassa. This $60 \mathrm{~km}$ journey is very dangerous and many nocturnal passengers fall victim to rough seas or the sharp coral reefs that surround Mayotte (Muenger 2011: 46). Despite these very real dangers, there still is a huge immigrant population on Mayotte. According to official statistics, 40 per cent of the island's population does not hold French citizenship (INSEE 2010: 34). The French government has reacted to these migratory movements with an uncompromising deportation practice. In 2010 alone, more than 24.000 people were arrested and deported from Mayotte - equaling almost ten per cent of the island's total population (World Policy Institute 2011). By this, the French government can also demonstrate a tough stance on 'illegal' migration from Africa towards the other EU member states (Muenger 2011: $54 \mathrm{ff}$.).

\section{The installation set-up}

17 A Tale of Two Islands seeks to explore this complex and contested postcolonial space in the form of a cinematographic installation (Rebentisch 2012). It consists of two films that are projected simultaneously onto two screens that face each other. Both films were shot in the major port areas of both islands, in Dzaoudzi, the old colonial capital of Mayotte, and in Anjouan's capital, Mutsamudu. I have chosen these very concrete places as locations for the films because they form the stage for the everyday drama of migration and deportation that connects both islands. Following Doreen Massey, I was interested in the transnational trajectories inscribed in both places, in their internal and external relations. 


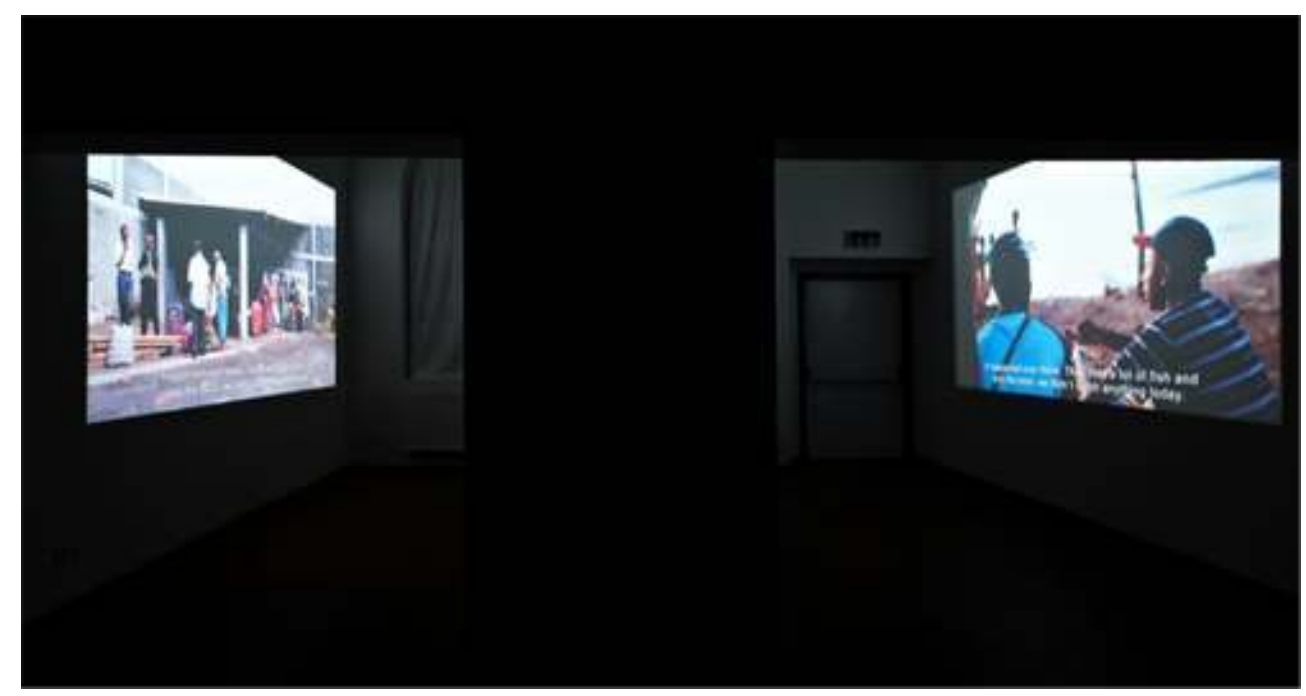

Kassel International Film- and Video Festival/ Sven Heine.

The first of the two places that form the setting of the installation is actually nothing more than an unspectacular metal-grilled window that my camerawoman Paola Calvo and I encountered during the first week of fieldwork in Mayotte's Dzaoudzi harbour. Almost every afternoon we saw crowds of people gathering in front of this window, chatting and seemingly waiting for something. When talking to some of the bystanders one day, we learned that they were the friends and relatives of Comorians who were about to be deported to Anjouan and that they came to see them off, and, if possible, give them some money to help them upon their forced return. Through the window bars, they pointed to a ferry waiting at the landing stage, the Princesse Caroline, apparently the vessel the French use for the deportations. Shortly after these conversations, an old French city bus, accompanied by police cars, arrived at the place. We learned that this bus brought the deportees from the detention centre in Pamandzi to the ferry. As soon as the deportees departed from the bus, the waiting group became animated. Some waived and shouted to get the attention of their kin, while others bargained through the grills with local members of the boat crew so they would hand over letters or some notes to the involuntary passengers. Through their relatives, we heard some of the deportees' stories. Most of them became the victims of one of the infamous raids that the French police conducts at work places, or plainly in the streets and public spaces in search of sans papiers. Others had been caught at sea before even arriving on Mayotte. For many of them, it was the second or even third deportation from the island.

When we came back the next morning, the scene had somehow changed. This time, the window was open and served as the ticket counter and baggage drop-off for the Maria Galanta, the only regular tourist ferry to Anjouan. The place was jam-packed with local tourists, mostly Mahorans visiting their families on the neighbouring island. All passengers carried absurd amounts of luggage. We spotted TV-sets, piles of clothing and huge cans of milk powder. We were told that these were all meant for relatives living on Anjouan, where these kinds of goods are not as readily available. As up to 70 kilos of baggage were allowed on each ticket, many Mahorans just came to the counter to find a passenger who would take their parcels along and make sure it would reach their kindred. The place thus had transformed into a giant post office, channelling the support 
for the economically weak sister island. When we returned a few hours later, the Maria Galanta had still not embarked, yet again we saw a crowd of people waiting in front of the now barred window. At this very moment, the familiar city bus appeared on the scene and we learned that the government buys all the unoccupied seats on the tourist boat to fill it up with deportees. Hence, this place was the site of fascinating transformations. We felt that the close proximity between tourism and deportation, support and separation expressed the whole drama caused by the political separation of both islands.

\section{Excerpts from A Tale of Two Islands - Mayotte.}

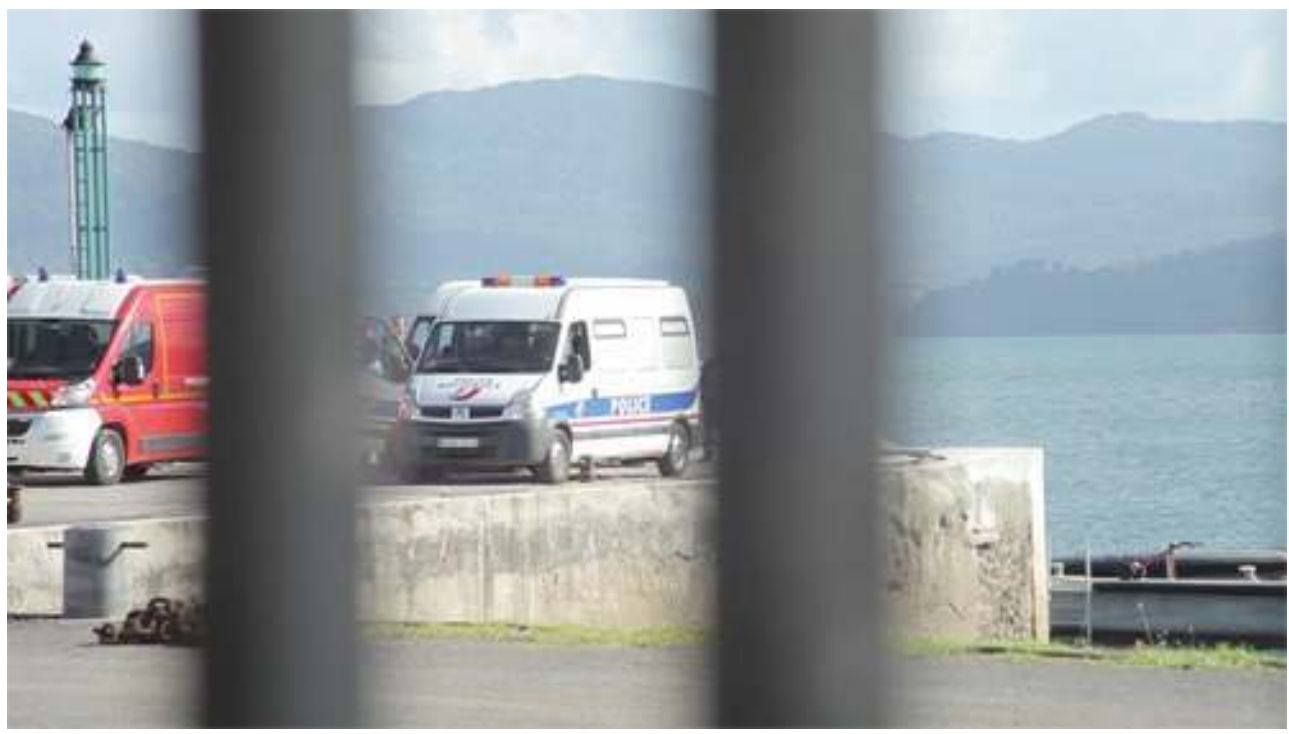

Click here to watch video: https://vimeo.com/80787993

Steffen Köhn

20 When we continued our fieldwork on the other side of the border, we found the counterpart of this place in a little strip of beach right next to the harbour of Mutsamudu. Here, locals kept their livestock, fishermen embarked in the morning to do their business, and unemployed men discussed local politics while observing the arrival of the ferries from Mayotte that brought would-be migrants back to the Comoros. Most importantly, however, we learned that it was from this relatively hidden part of the coast that traffickers offered the night-time journey across the border. While we were not allowed to film such an attempt at crossing, we could still capture the conversations of the locals who all had their opinion on the dangers and rewards of an attempt to make it to Mayotte. Moreover, the slow rhythm of life here offered a strong contrast to the much faster pace on the more developed French island. 


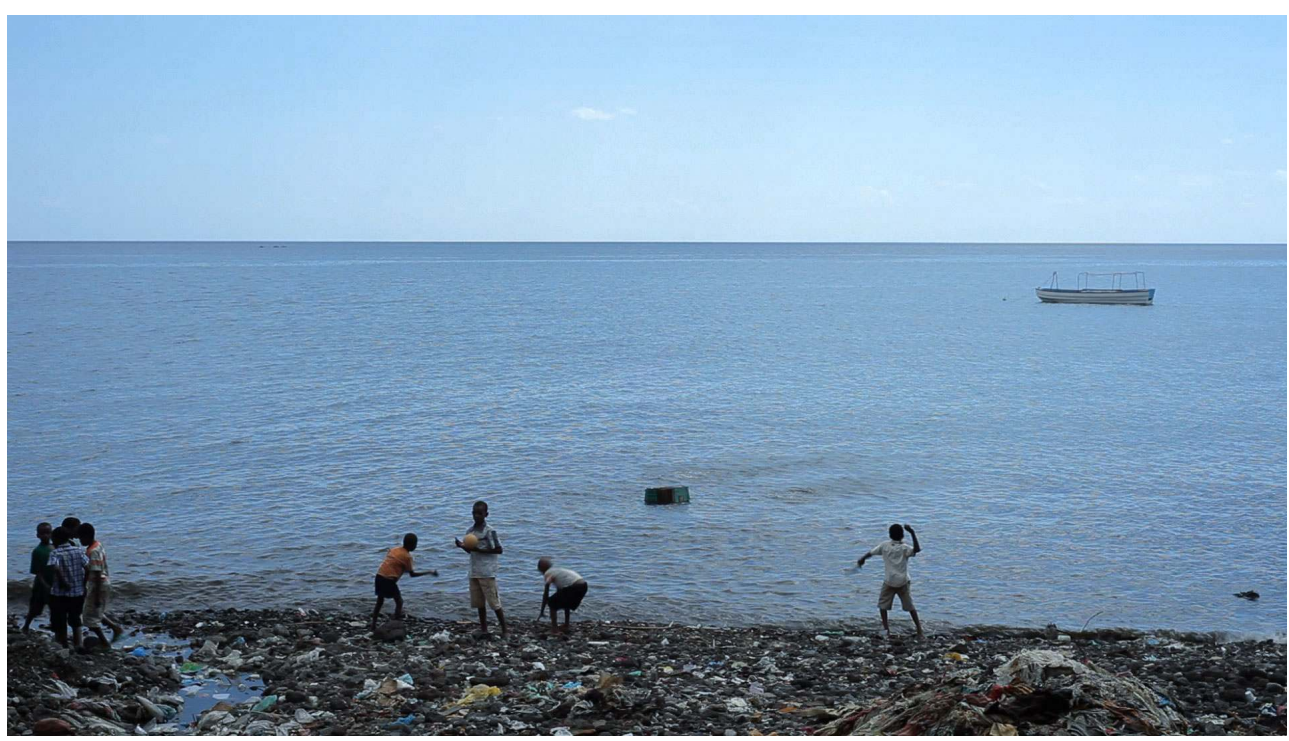

Click here to watch video: https://vimeo.com/80355709

Steffen Köhn

21 As the excerpts from both films that make up the installation hopefully have conveyed, we approached both these places through the cinematic techniques of observational filmmaking. We decided for the use of long sequence shots as our main stylistic device in order to explore the slow transformations occurring in both places in a more or less intact spatial-temporal unity. We further hoped that our phenomenological interest in the materiality and sensoriality of place would allow us to also convey something of our protagonists' emplacement in their particular lifeworlds. As David MacDougall in To Live with Herds, we sought to create such a sense of emplacement by immersing the audience in the perspective of our filmic subjects through the frequent use of POV shots and subjective framing. In the 'Mayotte'-film, for example, the constant alteration between the wider shots of the waiting relatives and the subjective long lens shots of the deportations that we filmed through the window bars serve to implicate the viewers in the perceptive horizon of our protagonists. As these shots are sutured through a very conjunctive style of editing, both films construct a coherent cinematic space that the viewer can explore from the unique point of view of the subjects emplaced in it.

This consistent 'human observer' perspective, which both films offer, is, however, disrupted by the fact that in the installation the films are projected simultaneously onto two opposing screens. Thus, it is impossible to see both films at the same time. The viewers' immersion into the perspective of one of the films thus ends whenever they feel that they have to divert their attention to the other screen. The audience is thus invited to perform their own parallel editing by simply turning their heads. Like Kiener's ethnographic cinema of montage, A Tale of Two Islands in this way introduces an aesthetic form that is capable of saying "both ... and," "neither ... nor": North and South, here and there, to left and right, inside and outside, subjective and objective“ (Kiener 2008: 397 ff.). Hence, the installation offers what could be termed a bifocality of perspectives: It not only allows for an immersion into the situated viewpoints of the filmed subjects (as in MacDougall's observational approach), but also demands a reflexive investment of the spectator (as in Kiener's montage aesthetics). As the viewer finds her/himself virtually 
placed 'in-between' both lifeworlds, s/he has to create the links between both films on a cognitive level. Thus, each of the two individual films offers by itself a micro perspective on the grounded reality of concrete places, while the confrontation of the screens in the exhibition space at the same time introduces a macro perspective that conveys their ambiguous relationship within a larger transnational space. The installation therefore fuses two scales of analysis that have remained contradictory in the aesthetic approaches of MacDougall and Kiener: the local and the global, the lifeworld and the system.

\section{Conclusion}

To conclude my argument, I briefly want to discuss the potential that working with multiple screens and projections - a practice still very marginal within our discipline might offer visual anthropology and ethnographic filmmaking. As the example of A Tale of Two Islands has hopefully suggested, the arrangement of ethnographic material in such a form inherits great analytical possibilities. In recent years, many anthropologists have expressed the need for multivocal and multiperspectival approaches, be it in postmodern practices of representation or in methodologies of multi-sited fieldwork. In text or film (the dominant media of ethnographic representation) however, these different voices and perspectives can only be arranged in temporal succession. The forms of spatial montage we encounter in the multi-screen video installation in contrast transcend the linearity of these media as they allow the viewer to explore relations between multiple locales, actors and situations as they are presented simultaneously on different screens. In A Tale of Two Islands, for example, the viewer can, while gradually discovering the manifold visible and invisible connections that exist between both islands, at any point also muse on the stark contrast between the opulent colonial architecture around the port of Dzaoudzi and the run-down facilities in Mutsamudu that rather reveal the postcolonial inequalities that separate Mayotte and Anjouan.

\section{A Tale of Two Islands - Splitscreen}

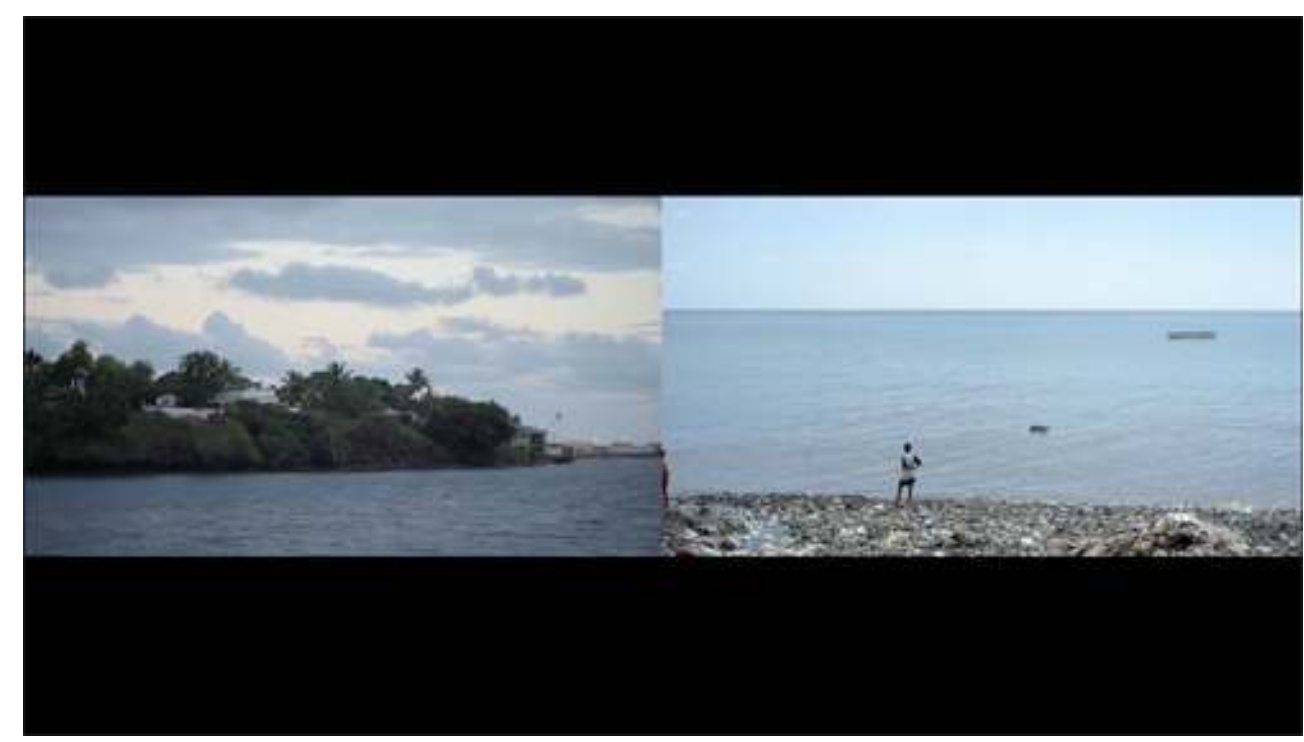

Click here to watch video: https://vimeo.com/81262137

Steffen Köhn 
, the spectators are much freer to compare and juxtapose the material presented to them on their own, without being guided by a linear narrative progression. Hence, in this mode of representation, we encounter a somewhat different role of anthropological authorship. The ethnographer here is not (only) the author or director, but the designer of an 'activated space' (Mondloch 2010) in which the actual material environment of an exhibition space mirrors the complex spatial formations that transnationalism, as a prolific social force, has brought about.

\section{BIBLIOGRAPHY}

Amelina, Anna, Thomas Faist, Nina Glick Schiller, and Devrimsel Nergiz. 2012. Beyond Methodological Nationalism: Research Methodologies for Cross-Border Studies. London: Routledge Appadurai, Arjun.1988. Putting Hierarchy In Its Place. Cultural Anthropology 3(1). 36-49.

Appadurai, Arjun 1996. Modernity at Large. Cultural Dimensions of Globalization. Minneapolis: University of Minnesota Press.

Aydemir, Murat and Alex Rotas, eds. 2008. Migratory Settings (Thamyris/Intersecting: Place, Sex \& Race). Amsterdam and New York: Rodopi.

Boisadam, Philippe. 2009. Mais que faire de Mayotte? Chronologie commenté "d'une affaire aussi dérisoire" (1841-2000). Paris: L'Harmattan.

Bordwell, David and Kristin Thompson. 2010. Film Art: An Introduction. $9^{\text {th }}$ Rev. Edition. New York: Mcgraw-Hill.

Castells, Manuel. 2000a. The Rise of the Network Society. The Information Age: Economy, Society and Culture Vol. I. 2nd Rev. Edition. Cambridge, MA; and Oxford, UK: Blackwell.

Castells, Manuel. 2000b. End of Millennium. The Information Age: Economy, Society and Culture Vol. III. 2nd Rev. Edition. Cambridge, MA and Oxford, UK: Blackwell.

Castells, Manuel. 2004. The Power of Identity. The Information Age: Economy, Society and Culture Vol. II. 2nd Rev. Edition. Cambridge, MA and Oxford, UK: Blackwell.

Clifford, James. 1997. Routes. Travel and Translation in the Late Twentieth Century. Cambridge, MA: Harvard University Press.

Cresswell, Tim. 2002. Introduction: Theorizing Place. In Placing Mobility, Mobilizing Place (Thamyris/ Intersecting: Place, Sex \& Race), ed. Tim Cresswell, Amsterdam and New York: Rodopi. 11-32.

Danusiri, Aryo, dir. 2011. The Fold. Documentary Educational Resources. $12 \mathrm{~min}$.

Deleuze, Gilles. 1986. Cinema 1: The Movement-Image. Trans. Hugh Tomlinson and Barbara Habberjam. London: The Athlone Press.

Grimshaw, Anna 2001. The Ethnographer's Eye: Ways of Seeing in Anthropology. Cambridge: Cambridge University Press.

Grimshaw, Anna and Amanda Ravetz. 2009. Observational Cinema. Anthropology, Film, and the Exploration of Social Life. Bloomington and Indianapolis: Indiana University Press. 
Hannerz, Ulf. 1996. Transnational Connections - Culture, People, Places. London: Routledge.

Henley, Paul. 2004. "Putting Film to Work: Observational Cinema as Practical Ethnography." In Working Images: Visual Research and Representation in Ethnography, eds. Sarah Pink, Laszlo Kurti, Ana Isabel Afonso. London and New York: Routledge. 109-130

INSEE (Institut national de la statistique et des études économiques). 2010. Tableau Économique de Mayotte. Édition 2010.

Kiener, Wilma 1990. dir. Ixok-Woman. Matzka-Kiener Filmproduktion. 90 min.

Kiener, Wilma 2008. The Absent and the Cut. Visual Anthropology 21(5): 393-409.

Köhn, Steffen 2012 dir. A Tale of Two Islands. Arsenal Experimental. Two-channel video installation. $16 \mathrm{~min}$, loop.

Köhn, Steffen. 2013. Organising Complexities: the Potential of Multi-screen Video Installations for Ethnographic Practice and Representation. Critical Arts: South-North Cultural and Media Studies, 27:5, 553-568

Lefebvre, Henri. 1991 The Production of Space, trans. Donald Nicholson-Smith, Oxford: Basil Blackwell.

MacDougall, David. 1972. To Live with Herds. University of California / Rice University Media Center. 70 mins.

MacDougall, David. 1998. Transcultural Cinema. Princeton. Princeton University Press.

Malkki, Liisa. 1992. "National Geographic: The Rooting of Peoples and the Territorialization of National Identity among Scholars and Refugees". Cultural Anthropology, Vol. 7, No. 1. 24-44.

Marcus, George. 1994. The Modernist Sensibility in Recent Ethnographic Writing and the Cinematic Metaphor of Montage. In Visualizing Theory Selected Essays from VAR 1990-1994, ed. L. Taylor, 37-53. New York: Routledge.

Marcus, George. 1995. Ethnography In/Of the World System. The Emergence of Multi-Sited Ethnography. Annual Review of Anthropology 24. 95-117.

Massey, Doreen. 2005. For Space. London: Sage.

Mondloch, Kate. 2010. Screens: Viewing Media Installation Art. Minneapolis: University of Minnesota Press.

Muenger, Laura. 2011. Im Kwassa-Kwassa nach Mayotte. Migrationsprozesse und sozialer Wandel in einem (post-)kolonialen Kontext. Working Paper No. 53, Institute for Social Anthropology. Bern: University of Bern.

Rebentisch, Juliane. 2012. Aesthetics of Installation Art. Berlin: Sternberg Press.

Rodman, Margaret C. 2003. Empowering Place. Mulilocality and Multivocality. In: Anthropology of Space and Place: Locating Culture, eds. Setha M. Low and Denise Lawrence-Zúñiga. Malden, MA: Blackwell. 204-223.

Sheller Mimi and John Urry. 2006. The New Mobilities Paradigm. Environment and Planning A 38(2): 207-226.

Soja, Edward W. Thirdspace: Journeys to Los Angeles and Other Real-and-Imagined Places. Oxford: Basil Blackwell. 
Suhr, Christian and Rane Willerslev. 2012. Can Film Show the Invisible? The Work of Montage in Ethnographic Filmmaking. Current Anthropology. 53(3): 282-301.

Suhr, Christian and Rane Willerslev, eds. 2013. Transcultural Montage. New York: Berghahn.

Taussig, Michael. 1987. Shamanism, Colonialism, and the Wild Man: A Study in Terror and Healing. Chicago: University of Chicago Press.

Taussig, Michael. 2004. My Cocaine Museum. Chicago: University of Chicago Press.

Taylor, Lucian. 1996. Iconophobia. Transition. No. 69. 64-88

Urry, John 2003. Global Complexity. Cambridge, UK and Oxford: Polity Press and Blackwell.

Willerslev, Rane and Olga Ulturgashewa. 2007. The Sable Frontier: The Siberian Fur Trade as Montage. Cambridge Anthropology 26(2): 79-100.

World Policy Institute. 2011. The Newest French Department. Last modified April 14 2011. http:// www.worldpolicy.org/blog/2011/04/14/newest-french-department (accessed 05 December 2013).

\section{NOTES}

1. According to Clifford (1983: 118), this is the magic formula by which the ethnographer claims her/his interpretive authority.

2. There are some other well-known rules and techniques for establishing coherent cinematic spaces. Spatial continuity in movement-image cinema, for example, demands that all space in which the action occurs is introduced by an establishing shot. Within a once established cinematic space, the 180-degree rule defines the on-screen spatial relationship between a character and another character or an object along an imaginary axis. By keeping the camera on one side of this axis for every shot, their positions will appear consistent throughout the scene. Match on action cutting then creates a visual bridge between two shots taken from different perspectives by having a character begin an action in the first and carry it on in the next, thus making the change of angles go unnoticed. For an in-depth description of continuity editing, see Bordwell and Thompson 2010.

\section{ABSTRACTS}

This article explores experimental approaches to the representation of space and place in anthropology. Drawing on examples from the history of visual anthropology, it will show how (implicit or explicit) anthropological conceptions of space are inscribed in the construction of cinematic space in ethnographic films. Drawing on examples by Wilma Kiener and Aryo Danusiri, the article tests the idea that the practices of contemporary experimental film and video art might propose new possibilities for conveying the complexity of transnational connections in today's globalized world. By introducing a recent video installation by the author, it then discusses how the actual material environment of an exhibition space may be creatively used to map the new spatial formations that migration as a social movement has brought about. Hence, 
the article argues for an understanding of the role of the anthropologist as a designer of 'activated spaces' (Mondloch 2010) that disrupt habitual viewing conventions.

Este artículo explora diferentes estrategias experimentales en relación a la representación del espacio y del lugar en antropología. Inspirándose en ejemplos de la historia de la antropología visual, este texto pretende mostrar cómo -implicita o explícitamente- ciertas concepciones antropológicas sobre el espacio se inscriben en la construcción del espacio cinematico de los filmes etnográficos. Tomando como base ejemplos de Wilma Kiener y Aryo Danusiri, el artículo discute la idea de que las practicas propias del cine experimental contemporáneo y del vídeo-arte pueden aportar nuevas posibilidades para dar cuenta de la complejidad de las conexiones transnacionales del mundo globalizado de hoy. Mediante la presentación de una instalación de vídeo reciente realizada por el mismo autor, este artículo discute cómo el entorno material de un espacio expositivo puede ser utilizado de forma creativa para representar las nuevas formaciones espaciales que la migración, en tanto que movimiento social, ha traído consigo. En consecuencia, el artículo argumenta a favor de una concepción del papel del antropólogo como diseñador de "espacios activados" (activated spaces) (Mondloch 2010) que distorsionan la convenciones visuales establecidas.

Cet article explore des approches expérimentales afin de rendre compte des notions d'espace et de lieu en anthropologie. A partir d'exemples tirés de l'histoire de l'anthropologie visuelle, cet article démontre comment d'une manière implicite ou explicite des conceptions anthropologiques de l'espace font partie intégrante de l'espace cinématographique dans les films ethnographiques. En prenant appui sur des exemples tirés des travaux de Wilma Kiener et Aryo Danusiri, cet article teste l'idée que dans les films expérimentaux contemporains et dans les vidéos d'art de nouvelles possibilités peuvent apparaître pour traduire la complexité des connections transnationales dans le monde actuel globalisé. En présentant une installation réalisée par l'auteur, l'article présente la façon dont l'environnement matériel d'un espace d'exposition peut d'une manière créative proposer une configuration des nouvelles réalités spatiales que la migration, mouvement social à part entière, a créée. Ainsi, l'article défend l'interprétation du rôle de l'anthropologiste comme un concepteur d'espaces actifs (Mondloch 2010) qui perturbent les conventions visuelles habituelles.

\section{INDEX}

Keywords: ethnographic film, cinematic space, video art, anthropology of space and place, montage

Palabras claves: cine etnográfico, espacio cinemático, video-arte, antropología del espacio y del lugar, montaje

Mots-clés: Film ethnographique, espace cinématographique, art video, anthropologie de l'espac et des lieux, montage

\section{AUTHOR}

\section{STEFFEN KÖHN}

Assistant Professor, Freie Universität Berlin

steffen.koehn@fu-berlin.de 